\title{
Levels of soluble fms-like tyrosine kinase one in first trimester and outcomes of pregnancy: a systematic review
}

\author{
Marni Jacobs ${ }^{1 \dagger}$, Natasha Nassar ${ }^{1{ }^{*}+}$, Christine L Roberts ${ }^{1,2}$, Ruth Hadfield ${ }^{1}$, Jonathan M Morris ${ }^{1,2}$ and \\ Anthony W Ashton'
}

\begin{abstract}
Angiogenic factors are involved in formation of new blood vessels required for placental development and function; and critical for fetal growth and development. Soluble fms-like tyrosine kinase 1(sFlt-1) is an antiangiogenic protein that inhibits formation of new blood vessels resulting in potential pregnancy complications. The objective of this study was to undertake a systematic review to assess levels of sFlt-1 in early pregnancy and association with adverse pregnancy outcomes. PubMed and Medline databases and reference lists were searched up to July 2010. Inclusion criteria were pregnant women, blood sample taken during first trimester and assessment/reporting of sFlt-1 concentrations and subsequent pregnancy complications. Twelve relevant studies were identified of 71 to 668 women. No pooling of results was undertaken due to variation in sFlt-1 concentrations (range, 166-6,349 pg/ml amongst controls), samples used (serum, plasma), different summary statistics (mean, median, odds ratio) and outcome definitions applied. Levels of sFlt-1 were generally higher among women who developed preeclampsia (11 studies) or gestational hypertension (two studies), but not significantly different to normotensive women in most studies. There was no consistent pattern in association between sFlt-1 concentrations and fetal growth restriction (4 studies); and levels were non-significantly higher for women with postpartum bleeding (1 study) and significantly lower for stillbirths (1 study).This review found no clear evidence of an association between sFlt-1 levels in first trimester and adverse pregnancy outcomes. However, findings were affected by methodological, biological and testing variations between studies; highlighting the need for consistent testing of new biomarkers and reporting of outcome measures.
\end{abstract}

\section{Background}

Despite appropriate antenatal care, unforeseen pregnancy complications still arise. Adverse pregnancy outcomes such as preeclampsia, fetal growth restriction and stillbirth may share the common basis of abnormal placentation [1,2]. Placental development is facilitated by the coordinated and complex processes of vasculogenesis (de novo formation of blood vessels) and angiogenesis (formation of new blood vessels from pre-existing vessels), both prior to implantation and throughout gestation. Impairment of these processes may result in

\footnotetext{
* Correspondence: natasha.nassar@sydney.edu.au

+ Contributed equally

'Perinatal Research, Kolling Institute of Medical Research, University of Sydney, Royal North Shore Hospital, St Leonards, 2065, NSW, Australia Full list of author information is available at the end of the article
}

restricted blood flow to the fetus, increased maternal blood pressure and premature delivery [1-3].

Biomarkers of angiogenesis are proposed as potential predictors of adverse pregnancy outcomes [1-3]. Soluble fms-like tyrosine kinase (sFlt-1) is an anti-angiogenic protein and considered to be one of the most promising serum biomarkers identified to date [4,5]. sFlt-1 inhibits vascular endothelial growth factor and placental growth factor signaling, attenuating the formation of new blood vessels and promoting maturation of those vessels that have already been created. sFlt- 1 has been implicated in the pathogenesis of preeclampsia when infusion of recombinant protein into rodents produced many of the symptoms of this enigmatic disease [6].

Although increases in sFlt-1 concentrations are expected during the second and third trimester of 
pregnancy, some studies have found rapidly increasing levels of this protein to arrest placental development, resulting in pregnancy complications [4,5]. In particular, elevated levels of sFlt- 1 have been reported in the second and third trimesters among women with pregnancies complicated by preeclampsia compared to women with normal pregnancies $[5,7,8]$. Increased sFlt-1 expression in the maternal circulation during late pregnancy has also been found to occur among women with growth restricted fetuses compared to those with normally grown infants $[9,10]$, and in women with placental abruption; although results are inconsistent $[11,12]$.

Levels of anti-angiogenic proteins can be detected soon after conception, and may provide a means of screening for women at risk for developing these complications $[13,14]$. Most studies of sFlt-1 concentrations and pregnancy outcomes have been conducted late in pregnancy or at birth with timing of the results inadequate for use as a predictive screening tool. The potential advantages of first trimester screening include the opportunity to incorporate an additional test into existing, routine antenatal testing and identification of at-risk pregnancies at gestations when preventive interventions may be a realistic option. The aim of this study was to undertake a systematic review of published studies to determine whether $1^{\text {st }}$ trimester sFlt- 1 concentrations are associated with adverse pregnancy outcomes.

\section{Methods}

\section{Data Sources}

We identified relevant studies by searching PubMed and Medline databases to identify publications up to May 2011, using the terms: 'Flt-1' or 'VEGFR-1' in conjunction with one of the following: 'pregnancy', 'adverse pregnancy outcomes', 'pregnancy complications', 'stillbirth', 'preterm birth', 'prematurity', 'small for gestational age', 'SGA', 'IUGR', or 'preeclampsia'. Search limits were set to exclude non-human studies, research among men, or articles published in a language other than English. We also reviewed the reference lists of identified articles and relevant review articles on the subject to identify studies that may have been missed in the initial database search.

\section{Study Selection}

The criteria for inclusion in the present systematic review were any published studies which: i) investigated the relationship between sFlt-1 concentration in the blood (serum or plasma) of pregnant women during the first trimester (mean specimen collection prior to 14 weeks gestation) and subsequent pregnancy complications, and ii) provided mean or median measurements of sFlt-1 concentrations with standard deviations, risk estimates with $95 \%$ confidence intervals, or data permitting to the calculation of these. Case-reports, letters, and review articles were excluded from the current investigation. Pregnancy outcomes were pre-specified, and included: preeclampsia, stillbirth, preterm birth, small for gestational age (SGA), and intrauterine growth restriction (IUGR).

Two reviewers independently assessed each study for inclusion in the review. Data were independently extracted from each paper by two reviewers onto a standard data extraction form. Discrepancies were resolved by consensus. Studies that met the inclusion criteria were assessed for: location of study, study design, study population, gestational age at screening, exposure assessment, sample size, and reported effect measure.

\section{Statistical Analysis}

We planned to undertake a meta-analysis of continuous data and apply the mean difference approach for each outcome where threshold levels of sFLT-1 were reported [15]. However, we were unable to pool results because there was significant variation in the selection of study populations, the quantification of sFlt-1 (evidenced by large variations in the reported levels), the samples used (serum or plasma), the choice of summary statistic (mean, median and OR) and outcome definitions. Thus, the general findings from the studies are reported and the percentage difference (positive or negative) in SFLT1 levels among women with or without adverse outcomes was calculated.

\section{Ethics}

No ethics approval was required.

\section{Results}

The primary search yielded 373 articles; and one additional paper was identified through PubMed-suggested related content. After screening the titles and abstracts of these studies, 29 publications were identified for further review based on stated inclusion criteria. Ultimately, twelve studies were included in the present analysis [16-27]. Figure 1 depicts the selection process, including reasons for the exclusion of identified publications. Examples of non-relevant outcomes identified were cancer, chronic lung disease, arthritis, and peripheral artery disease. Non-relevant exposures that were assessed included angiogenic proteins other than sFlt-1 (such as sEng and VEGF), non-relevant markers (such as IL-8 and IL-6), and lifestyle factors (such as smoking).

The characteristics of the twelve studies included in the final review are presented in Table 1. Screening was performed between 4 and 17 weeks gestation with mean age of gestation at screening ranging between 9 and 13.7 weeks. The majority of studies identified utilized a case-control study design with some studies nested 


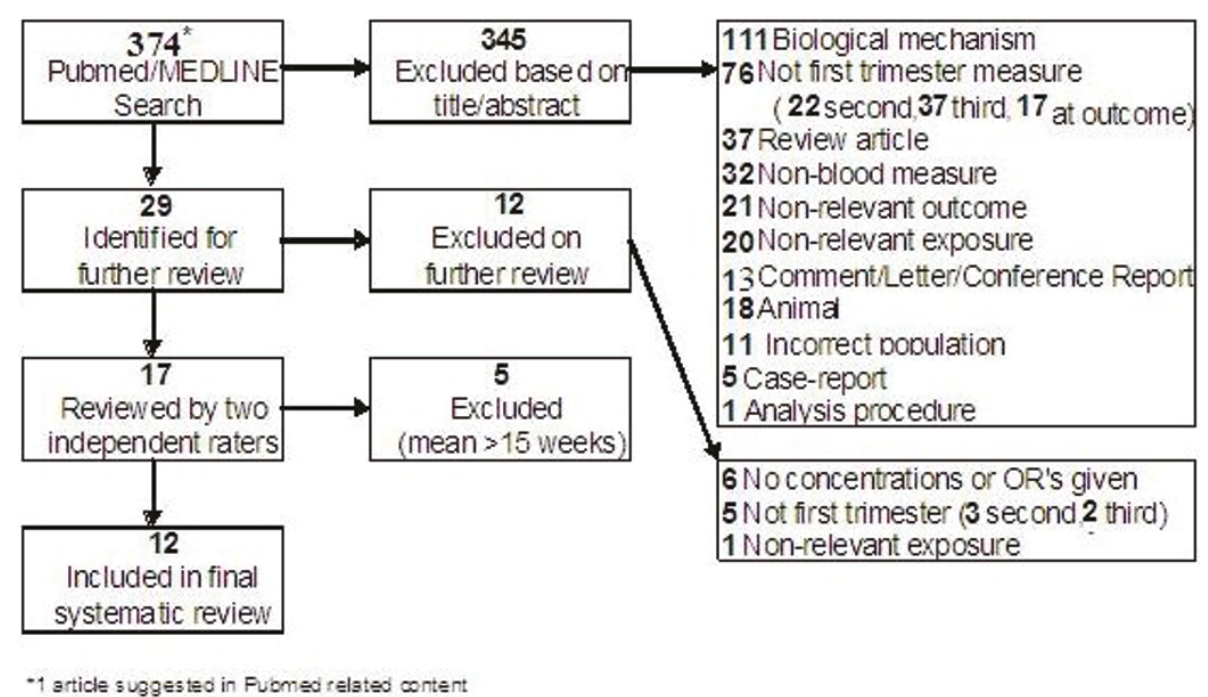

Figure 1 Identification of studies for inclusion in the systematic review.

within and based on serum samples and data collected as a part of larger randomized trials or cohort studies. There were two prospective cohort studies that included women attending for prenatal care $[25,26]$. One of these studies also included women from an obstetric medicine clinic [26].

The outcomes reported included preeclampsia (11 studies) [16-18,20-27], SGA or IUGR (four studies) $[18,21,22,24]$, gestational hypertension (two studies) $[22,26]$, and one study each evaluated excessive postpartum bleeding [19] and stillbirth [21]. Concentrations of sFlt-1 were presented either as mean or median concentrations, or as odds ratios (OR) for various levels of sFlt1 (continuous, quartiles, or deciles). While assessment of circulating sFlt-1 was performed using an ELISA testing kit (R\&D Systems Pty Ltd) according to manufacturers' guidelines, other aspects of testing and specimen storage varied between studies (Table 2). Analysis was performed on either serum or EDTA anti-coagulated plasma. Sample storage temperatures ranged from $-20^{\circ} \mathrm{C}$ to $-80^{\circ} \mathrm{C}$, and the intra- and inter-assay coefficients varied between laboratories along with sensitivity levels. Only three studies reported the dilution used $[16,19,23]$ and six laboratories conducted duplicate testing [20,22,24-27]. In addition, only one study explicitly reported how long the samples were stored for prior to testing [22], although two others referenced duration of sample storage in their discussion sections $[16,23]$ and another specified that none of the samples had previously been thawed and refrozen [27].

The outcome most often studied in these investigations was preeclampsia, with standard and consistent definitions used to define preeclampsia in all studies [16-18,20-27]. Investigators typically defined preeclampsia as new onset hypertension (systolic blood pressure $\geq 140 \mathrm{~mm} \mathrm{Hg}$ or diastolic blood pressure $\geq$ $90 \mathrm{~mm} \mathrm{Hg}$ ) occurring after 20 weeks gestation, with concurrent proteinuria ( $\geq 2+$ by dipstick or $\geq 300 \mathrm{mg}$ in 24 hours). In some cases, preeclampsia was examined in subgroups based on timing of diagnosis, either preterm $(<34$ or $<37$ weeks gestation) $[18,23,26,27]$ or term ( $\geq 37$ weeks gestation) $[18,26]$.

The results of the ten preeclampsia studies that reported either mean or median sFlt-1 concentrations are presented in Table 3 [16-18,20,22-27]. The concentrations of sFlt-1 varied greatly between the studies with levels in controls (normotensive women) ranging from 166 to $6,349 \mathrm{pg} / \mathrm{ml}$ and this did not appear to be related to the gestational age at testing. Eight studies assessed any preeclampsia or preeclampsia at term and reported the mean or median sFlt- 1 concentration during the first trimester. Of these, six studies found sFlt-1 levels among women with preeclampsia were $5 \%$ to $15 \%$ higher compared to women with normal pregnancies $[16,17,20,22,24,25]$; however, this elevation was only statistically significant in one study [16]. One study of term preeclampsia reported a statistically significant lower concentration (by 19\%) among term preeclamptic women [18], while another found nonsignificant lower concentrations [26]. The findings were similarly variable in the three studies that analyzed preterm preeclampsia (< 37 weeks gestation) separately $[18,23,26]$. Two studies $[18,23]$, found that concentrations of sFlt-1 were significantly lower (by $19 \%$ to $27 \%$ ) during the first trimester among women diagnosed with preterm preeclampsia $[18,23]$. However a third study found significant increases in maternal sFlt-1 (by up to $40 \%$ ) among women with preterm 
Table 1 Characteristics of studies assessing sFlt-1 in first trimester of pregnancy

\begin{tabular}{|c|c|c|c|c|c|c|}
\hline Reference & Location & $\begin{array}{l}\text { Study } \\
\text { Design }\end{array}$ & $\begin{array}{l}\text { Type of sample } \\
\text { and gestational } \\
\text { age at screening }\end{array}$ & Participants & Outcome(s) & $\begin{array}{l}\text { s-FLT1 } \\
\text { Summary } \\
\text { measure }\end{array}$ \\
\hline Akolekar, 2010 & $\begin{array}{l}\text { United } \\
\text { Kingdom }\end{array}$ & $\begin{array}{l}\text { nested case- } \\
\text { control }\end{array}$ & $\begin{array}{l}\text { Plasma } \\
11-13 \text { weeks }\end{array}$ & $\begin{array}{l}\text { Singleton pregnancies } \\
\text { Exclusions: hypertension but uncertainty about a } \\
\text { diagnosis of preeclampsia }(n=30) \text {, preeclampsia } \\
\text { but stored blood not available }(n=57)\end{array}$ & $\begin{array}{l}\text { Preeclampsia } \\
<34 \text { weeks } \\
\geq 34 \text { weeks }\end{array}$ & median \\
\hline Baumann, 2008 & Switzerland & case-control & $\begin{array}{l}\text { Serum } \\
11-14 \text { weeks }\end{array}$ & $\begin{array}{l}\text { Singleton pregnancies } \\
\text { Exclusions: women with history of hypertensive } \\
\text { disorders, immunological diseases, HELLP, or PE < } \\
34 \text { weeks }\end{array}$ & Preeclampsia & $\begin{array}{l}\text { mean, } \\
\text { median }\end{array}$ \\
\hline $\begin{array}{l}\text { Chaiworapongsa, } \\
2005\end{array}$ & Chile & case-control & $\begin{array}{l}\text { Plasma } \\
7-16 \text { weeks }\end{array}$ & $\begin{array}{l}\text { Singleton pregnancies. Exclusions: pregnancies with } \\
\text { fetal anomaly or demise, vaginal bleeding, women } \\
\text { with serious medical conditions, chronic } \\
\text { hypertension, asthma requiring medication, or } \\
\text { requiring the use of anti-platelet or non-steroidal } \\
\text { anti-inflammatory drug. }\end{array}$ & Preeclampsia & mean \\
\hline Erez, 2008 & Chile & $\begin{array}{l}\text { nested case- } \\
\text { control }\end{array}$ & $\begin{array}{l}\text { Plasma } \\
\text { 6-15 weeks }\end{array}$ & Singleton pregnancies. & $\begin{array}{l}\text { SGA, } \\
\text { Preeclampsia } \\
\text { (preterm and } \\
\text { term) }\end{array}$ & $\begin{array}{l}\text { median, } \\
\text { OR }\end{array}$ \\
\hline Eskild, 2008 & Norway & $\begin{array}{l}\text { nested case- } \\
\text { control }\end{array}$ & $\begin{array}{l}\text { Serum } \\
4-12 \text { weeks }\end{array}$ & Normotensive pregnant women only. & $\begin{array}{l}\text { Excessive } \\
\text { postpartum } \\
\text { bleeding }\end{array}$ & mean \\
\hline Lynch 2010 & $\begin{array}{l}\text { USA } \\
\text { 2005-2008 }\end{array}$ & $\begin{array}{l}\text { prospective } \\
\text { cohort }\end{array}$ & $\begin{array}{l}\text { Serum } \\
10-15 \text { weeks }\end{array}$ & $\begin{array}{l}\text { Singleton pregnancies, women presenting for } \\
\text { prenatal care } \\
\text { Exclusions: intrauterine fetal loss, gestational } \\
\text { hypertension }\end{array}$ & Preeclampsia & mean \\
\hline Noori 2010 & $\begin{array}{l}\text { United } \\
\text { Kingdom }\end{array}$ & $\begin{array}{l}\text { prospective } \\
\text { cohort }\end{array}$ & $\begin{array}{l}\text { Serum } \\
10-17 \text { weeks }\end{array}$ & $\begin{array}{l}\text { Singleton pregnancies from routine screening }(n= \\
114) \text { and an obstetric medicine clinic }(n=45)\end{array}$ & $\begin{array}{l}\text { Preeclampsia, } \\
\text { (preterm and } \\
\text { term) } \\
\text { Gestational } \\
\text { hypertension }\end{array}$ & $\begin{array}{l}\text { geometric } \\
\text { mean }\end{array}$ \\
\hline Rana S, 2007 & $\begin{array}{l}\text { USA, } \\
2001-2003\end{array}$ & $\begin{array}{l}\text { nested case- } \\
\text { control }\end{array}$ & $\begin{array}{l}\text { Serum } \\
11-13 \text { weeks }\end{array}$ & $\begin{array}{l}\text { Singleton pregnancies delivered }>20 \text { weeks } \\
\text { (livebirths) gestation. } \\
\text { Exclusions: women with history of hypertension, } \\
\text { hypertension } 6 \text { weeks postpartum, renal disease, or } \\
\text { diabetes. }\end{array}$ & Preeclampsia, & mean \\
\hline Smith, 2007 & $\begin{array}{l}\text { Scotland, } \\
\text { 1997-99 }\end{array}$ & $\begin{array}{l}\text { nested case- } \\
\text { control }\end{array}$ & $\begin{array}{l}\text { Serum } \\
10-14 \text { weeks }\end{array}$ & $\begin{array}{l}\text { Singleton pregnancies. } \\
\text { Exclusions: stillbirths due to congenital anomalies or } \\
\text { rhesus disease. }\end{array}$ & $\begin{array}{l}\text { Preeclampsia } \\
\text { SGA } \\
\text { Preterm } \\
\text { (extreme and } \\
\text { moderate) } \\
\text { Stillbirth }\end{array}$ & OR \\
\hline Thadhani R, 2004 & $\begin{array}{l}\text { USA, } \\
2001-2003\end{array}$ & $\begin{array}{l}\text { nested case- } \\
\text { control }\end{array}$ & $\begin{array}{l}\text { Serum } \\
\text { 8-14 weeks }\end{array}$ & $\begin{array}{l}\text { Singleton pregnancies }>20 \text { weeks gestation. } \\
\text { Exclusions: women with hypertension }>6 \text { weeks } \\
\text { postpartum, history of thyroid, liver, or chronic renal } \\
\text { disease, or chronic hypertension. }\end{array}$ & $\begin{array}{l}\text { Preeclampsia, } \\
\text { Gestational } \\
\text { hypertension } \\
\text { SGA }\end{array}$ & mean \\
\hline Vatten LJ, 2007 & $\begin{array}{l}\text { Norway, } \\
\text { 1992-1994 }\end{array}$ & $\begin{array}{l}\text { nested case- } \\
\text { control }\end{array}$ & $\begin{array}{l}\text { Serum } \\
4-12 \text { weeks }\end{array}$ & Singleton pregnancies & $\begin{array}{l}\text { Preeclampsia } \\
\text { (preterm and } \\
\text { term) }\end{array}$ & mean, OR \\
\hline Wathen KA, 2006 & $\begin{array}{l}\text { Finland, } \\
\text { 2001-2002 }\end{array}$ & $\begin{array}{l}\text { longitudinal } \\
\text { case-control }\end{array}$ & $\begin{array}{l}\text { Serum } \\
\text { 2-15 weeks }\end{array}$ & $\begin{array}{l}\text { Singleton pregnancies among Caucasian women } \\
\text { Exclusions: women with history of hypertension, } \\
\text { diabetes, chronic disease, or smoke }>5 \text { cigarettes/ } \\
\text { day. }\end{array}$ & $\begin{array}{l}\text { Preeclampsia } \\
\text { IUGR }\end{array}$ & $\begin{array}{l}\text { median, } \\
\text { OR }\end{array}$ \\
\hline
\end{tabular}

All blood testing done using an ELISA testing kit developed by R\&D Systems

$\mathrm{SGA}=$ small for gestational age; IUGR = intrauterine growth restriction

preeclampsia [26] (Table 3). Conversely, no statistically significant increase in the median sFlt-1 concentration among women with preeclampsia at $<34$ weeks or $\geq 34$ weeks gestation was reported in the final study [27].
Two studies also considered gestational hypertension (i.e. hypertension during pregnancy without proteinuria). Thadhani et al found similar first trimester sFlt-1 concentrations in women with gestational hypertension compared to normal controls $(942 \mathrm{pg} / \mathrm{mL}$ vs. $973 \mathrm{pg} / \mathrm{mL}$ 
Table 2 sFlt-1 testing characteristics

\begin{tabular}{|c|c|c|c|c|c|c|}
\hline Reference & Storage Temperature & Dilution & Duplicate Testing & Intraassay Coefficient & Interassay Coefficient & Sensitivity \\
\hline Akolekar, 2010 & $-80^{\circ} \mathrm{C}$ & & yes & & & $15 \mathrm{pg} / \mathrm{mL}$ \\
\hline Baumann, 2008 & $-30^{\circ} \mathrm{C}$ & $1: 3$ & & $3.8 \%$ & $7.0 \%$ & \\
\hline Chaiworapongsa, 2005 & $-70^{\circ} \mathrm{C}$ & & & $6.9 \%$ & $4.8 \%$ & $17.8 \mathrm{pg} / \mathrm{mL}$ \\
\hline Erez, 2008 & $-70^{\circ} \mathrm{C}$ & & & $3.9 \%$ & $1.4 \%$ & $17.0 \mathrm{pg} / \mathrm{mL}$ \\
\hline Eskild, 2008 & $-20^{\circ} \mathrm{C}$ & $1: 5$ & & & & $17 \mathrm{pg} / \mathrm{mL}$ \\
\hline Lynch, 2010 & $-80^{\circ} \mathrm{C}$ & & yes & & $9.9 \%$ & \\
\hline Noori, 2010 & $-70^{\circ} \mathrm{C}$ & & yes & & & $3.5 \mathrm{pg} / \mathrm{mL}$ \\
\hline Rana S 2007 & $-80^{\circ} \mathrm{C}$ & & yes & $3.5 \%$ & $8.1 \%$ & \\
\hline Smith, 2007 & & & & $10.4 \%$ & $14.9 \%$ & $5 \mathrm{pg} / \mathrm{mL}$ \\
\hline Thadhani, 2004 & $-80^{\circ} \mathrm{C}$ & & yes & $3.5 \%$ & $8.1 \%$ & \\
\hline Vatten, 2007 & $-20^{\circ} \mathrm{C}$ & $1: 5$ & & & & $17 \mathrm{pg} / \mathrm{mL}$ \\
\hline Wathen, 2006 & $-80^{\circ} \mathrm{C}$ & & yes & $5.0 \%$ & $8.2 \%$ & $5 \mathrm{ng} / \mathrm{L}$ \\
\hline
\end{tabular}

All blood testing done using ELISA testing kits developed by R\&D Systems.

respectively, $\mathrm{P}=0.52$ ) [22], while Noori et al found significantly higher mean concentrations among those with gestational hypertension $(2219 \mathrm{pg} / \mathrm{mL}$ vs $1729 \mathrm{pg} / \mathrm{mL}, \mathrm{P}$ $<0.01)$ [26].

Four studies investigated maternal sFlt-1 concentrations and IUGR or SGA $[18,21,22,24]$, however, the definition of the outcome varied between studies. Two studies defined SGA as a birth weight below the $10^{\text {th }}$ percentile for gestational age $[18,22]$, while a third defined SGA as a birth weight below the $3^{\text {rd }}$ percentile for gestational age [21]. Wathen et al. defined IUGR as birth weight at least 2 standard deviations below the national average for gestational age [24]. There was no consistent pattern in the association between sFlt-1 concentrations and IUGR in the three studies that examined this outcome. In two of the studies [22,24], levels of sFlt-1 among women with growth restricted infants were slightly higher compared with control women (1011 pg/mL vs. $973 \mathrm{pg} / \mathrm{mL}$ and $486 \mathrm{pg} / \mathrm{mL}$ vs. $432 \mathrm{pg} /$ $\mathrm{mL})$. However, the other study reported lower sFlt-1 concentrations among the SGA group $(1616 \mathrm{pg} / \mathrm{mL}$ vs $1788 \mathrm{pg} / \mathrm{mL}$ ) [18].

Two studies examined the dose-response between sFlt-1 levels and size at birth with conflicting results $[18,21]$. Erez et al. treated sFlt-1 as a continuous variable in a polytomous logistic model, adjusted for maternal age, BMI, and nulliparity; and found that compared to normal pregnancies, there was no association between increasing levels of sFlt-1 and delivery of an SGA neonate (OR 1.00; 95\%CI 0.99-1.00) [18]. In

Table 3 Results from studies assessing the association between $1^{\text {st }}$ trimester sFlt- 1 concentrations (pg/mL) and preeclampsia (PE)

\begin{tabular}{|c|c|c|c|c|c|c|c|c|}
\hline \multirow[t]{2}{*}{ Reference } & \multirow[t]{2}{*}{ Mean GA } & \multirow[t]{2}{*}{ Outcome } & \multicolumn{2}{|c|}{ Cases (Preeclampsia) } & \multicolumn{2}{|c|}{ Controls (normotensive) } & \multirow[t]{2}{*}{ P-value } & \multirow[t]{2}{*}{$\%$ difference $\dagger$} \\
\hline & & & $\bar{n}$ & Flt-1 concentration & $\mathrm{n}$ & sFlt-1 concentration & & \\
\hline \multicolumn{4}{|c|}{ Studies reporting mean concentrations } & mean, SD/SE & & mean, SD/SE & & \\
\hline Baumann, 2008 & 12.3 & $\mathrm{PE}$ (> 34 weeks) & 46 & $1764(757)$ & 92 & $1537(812)$ & 0.04 & +13 \\
\hline Chaiworapongsa, 2005 & 12.3 & PE & 34 & $546(271)$ & 37 & $464(260)$ & 0.10 & +15 \\
\hline Lynch, 2010 & 12.3 & PE & 31 & $1374(639)$ & 637 & $1313(521)$ & 0.5 & +5 \\
\hline \multirow[t]{2}{*}{ Noori, 2010} & 13.7 & $\mathrm{PE}$ (<37 weeks) & 10 & $2414(622)$ & 128 & $1729(85)$ & $<0.01$ & +40 \\
\hline & & $\mathrm{PE}$ ( $\geq 37$ weeks) & 10 & $1688(210)$ & 128 & $1729(85)$ & 0.19 & -2 \\
\hline Rana S, 2007 & $11-13^{*}$ & PE & 39 & $3500(300)$ & 147 & $3000(100)$ & 0.14 & +14 \\
\hline Thadhani, 2004 & 10.7 & PE & 40 & $1048(657)$ & 80 & $973(490)$ & $>0.05$ & +7 \\
\hline Vatten, 2007 & 9.0 & Preterm PE & 110 & 135 & 276 & 166 & 0.01 & -19 \\
\hline \multicolumn{4}{|c|}{ Studies reporting median concentrations } & median & & median & & \\
\hline \multirow[t]{2}{*}{ Akolekar 2010} & $11-13^{*}$ & PE (<34 weeks) & 30 & 7099 & 180 & 6349 & NS & +12 \\
\hline & & PE ( $\geq 34$ weeks) & 60 & 6840 & 180 & 6349 & NS & +8 \\
\hline \multirow[t]{2}{*}{ Erez, 2008} & 12.2 & PE (<37 weeks) & 17 & 1308 & 201 & 1788 & 0.03 & -27 \\
\hline & 12.2 & PE ( $\geq 37$ weeks) & 39 & 1448 & 201 & 1788 & 0.02 & -19 \\
\hline Wathen, 2006 & 13.7 & PE & 44 & 481 & 51 & 432 & $>0.05$ & +10 \\
\hline
\end{tabular}

${ }^{*}$ No mean gestational age (GA) provided

† $\%$ difference in case mean or median $1^{\text {st }}$ trimester sFLT-1 compared with the control level 
contrast, Smith et al. modeled increasing deciles of sFlt1 , and showed a tendency towards decreasing risk of SGA as levels of sFlt-1 increased, in both unadjusted models (OR 0.92; 95\%CI 0.88-0.96, $\mathrm{P}=0.02$ ) and models adjusted for maternal age, ethnicity, parity, BMI, height, smoking status, and hospital of delivery (OR 0.92 ; $95 \% \mathrm{CI} 0.82-1.00, \mathrm{P}=0.05$ ), suggesting the greatest risk for SGA was in the lowest decile of sFlt-1 concentration [21].

Of the other pregnancy outcomes assessed, sFlt-1 concentrations during first trimester were slightly, but not significantly higher for women who experienced a postpartum hemorrhage compared with those who did not $(230 \mathrm{pg} / \mathrm{mL}$ vs. $204 \mathrm{pg} / \mathrm{mL}$, respectively) [19]. While, compared to controls, the risk of stillbirth due to placental causes was highest in the lowest decile of sFlt-1 concentration (OR 0.71, 95\% CI 0.53-0.91, p < 0.01 ), with the risk attenuated with increasing levels of sFlt-1 [21].

\section{Discussion}

This systematic review provides no clear evidence for an association between sFlt-1 levels in the first trimester and adverse pregnancy outcomes. However, findings of this review were affected by methodological, biological and testing variations between studies, which highlight the need for consistent testing of new biomarkers and reporting of outcome measures.

The outcome most often investigated in these studies was preeclampsia; however, these studies do not provide a consensus as to the nature of the relationship between sFlt-1 concentrations during the first trimester of pregnancy and onset of preeclampsia. Although the majority of the studies suggest a higher level of sFlt-1 concentrations in women destined to develop preeclampsia at term, the elevated levels were not significantly different in most of the studies. Similarly, three studies that did not report the exact levels of sFlt-1 in first trimester reported no significant differences between women with and without preeclampsia [23,28-30]. This is consistent with the conclusions of Levine who found that levels didn't increase until approximately five weeks before the onset of clinical disease [5]. In contrast, preterm preeclampsia tended to be associated with lower sFlt-1 levels in first trimester. Despite these differences, one of the strengths of the preeclampsia studies was the consistency with which preeclampsia was defined and therefore differences in outcome assessment do not explain the dissimilarity of the results obtained. On the other hand, the studies were small and it is unclear whether the populations themselves are comparable. Although some studies stated that women with a history of hypertensive disorders and renal disease were excluded $[16,17,20,22,24]$, others did not $[18,23]$. This may be significant as findings from the two studies that did not exclude women with previous hypertension $[18,23]$ were in opposition to those that did $[16,17,20,22,24]$. The distribution of other predictors of preeclampsia such as parity, obesity, smoking and ethnicity [31], was reported in only few studies.

Similarly no conclusions could be drawn from the studies that examined the association between first trimester sFlt-1 levels and fetal growth restriction. These studies were complicated by a lack of consistency in the outcome definition and variation in testing procedures and reporting of sFlt-1 concentrations.

A number of factors, including methodological, biological and testing differences may have contributed to the variation in sFlt-1 concentrations observed in the studies included in our review. Variation in study location, characteristics of women, sample size and timing of serum screening may also impact on sFlt-1 measurements. Furthermore, the large variation in sFlt-1 levels in the control groups from the included studies also precludes comparisons. Reporting could be standardized by presenting the sFlt- 1 values as multiples of the median (MoM), rather than raw concentrations, as is standard practice in Down syndrome screening [32]. This would help account for variation between maternal characteristics, gestational age, settings and testing techniques, and MoM percentile cutoffs would allow for differentiation between groups. However, only one study included in our review recognized and employed this method [21].

Given that there are no established normative levels of sFlt-1 in pregnancy, it is difficult to assess how meaningful these differences are, or to define 'abnormal" versus 'normal' concentrations. Further, there is little information about the effect of maternal factors such as smoking and body mass index on sFlt-1 levels. Small studies have reported changes in sFlt-1 concentrations between first and second trimester [18] and non-significant differences between normal pregnancies and those affected with preeclampsia [20]. However, large, prospective studies in unselected, ethnically and geographically diverse pregnant populations with serial, longitudinal measurements of sFlt-1 levels throughout pregnancy are required to assess and define the natural progression of sFlt-1 levels in pregnancy.

The variation in sFlt-1 concentrations also underscores the need to understand and ensure results are comparable between different types of biological samples. Measurement of serum and plasma may not yield similar results. With plasma, the choice of anticoagulant can influence the results; for example EDTA chelates calcium and impedes the binding of samples in testing kits which targets a calcium dependent epitope. With serum, angiogenic factors released from platelets could 
mask the true levels being measured. The manufacturers' package reports mean sFlt- 1 concentration of 80 $\mathrm{pg} / \mathrm{ml}$ (range 55-123) and $114 \mathrm{pg} / \mathrm{ml}$ (range 75-179) for EDTA-plasma and serum, respectively ( $\mathrm{n}=35$ samples). If plasma samples give systematically lower concentrations than serum samples, then comparison between the two measures may not be reasonable.

Consistent testing practices across settings are also important to ensure comparability of findings. Technical differences in the storage and testing of samples may contribute to increased variability and unreliability of sFlt-1 measurements. The studies in this review varied in the length, method and temperature of sample storage, thawing of samples, duplicate testing; sensitivity of detection limits, and inter- and intra-assay coefficients of variation. Of particular importance may be temperature and length of storage, where samples stored for long periods at temperatures above -80 degrees may promote some degradation of proteins [22]. From the three studies that reported storage duration, these ranged from less than 2 years $[16,22]$ to more than 10 years [23]. Another factor that may have contributed to the inter-study variation in the findings is the number of freeze-thaw cycles samples were exposed to. Only one study specifically stated that tested samples were only thawed once [22], and since others made no such claims, it is difficult to draw any conclusions regarding the uniformity of the measures.

The large-scale usefulness of predictive biomarkers remains unclear and such research is rarely presented in a manner that allows translation to a population level. For example, a recent study suggesting that pregnancy associated plasma protein-A (PAPP-A), an antenatal maternal serum biomarker, could be used as an early marker for pregnancies at-risk of preeclampsia reported an odds ratio of 6.6 (95\% CI 2.2, 16.9), and concluded that decreased first trimester PAPP-A is a predictor of adverse pregnancy outcome [33]. However, extrapolating results from this paper suggests the marker would perform poorly at a population level, such that if 100,000 pregnancies were screened, approximately 5,000 women would be found to have abnormal PAPP-A levels, but of those, only 450 would develop preeclampsia compared to 1,425 among those with normal PAPP-A levels. Therefore, it is important to establish both the positive and negative predictive values of sFlt- 1 screening before recommending its use beyond a research setting.

\section{Conclusions}

Ideally, identification of high risk women early in pregnancy would allow for early interventions to be undertaken in hopes of reducing incidence of these outcomes. In the absence of effective interventions, a biomarker predictor of high risk patients could be used to identify women for enrolment in intervention or surveillance trials. The first trimester provides an opportunity to incorporate sFlt-1 testing into other routine testing done at the time. Screening during the $2^{\text {nd }}$ or $3^{\text {rd }}$ trimester may be too late for preventive interventions. The studies presented in this paper do not support a consensus regarding the efficacy of sFlt1 as a predictive tool for adverse birth outcomes. However, other biomarkers used alone or in combination with sFlt-1 may be more discriminating. This review underscores the need for uniform testing and reporting to establish the utility of sFlt-1 as a first trimester screening instrument.

\section{Acknowledgements}

This work was supported by an Australian National Health and Medical Research Council (NHMRC) Project Grant (\#632653). Christine Roberts is supported by a NHMRC Senior Research Fellowship (\#457078) and Natasha Nassar is supported by a NHMRC Career Development Award (\#632955).

\section{Author details}

${ }^{1}$ Perinatal Research, Kolling Institute of Medical Research, University of Sydney, Royal North Shore Hospital, St Leonards, 2065, NSW, Australia. 2Department of Obstetrics and Gynecology, Royal North Shore Hospital, St Leonards, 2065, NSW, Australia.

\section{Authors' contributions}

NN, CLR, JMM, RH and AWA conceived the study, MJ and NN wrote the study proposal and MJ conducted the literature search. Data extraction was undertaken by MJ, NN, CLR and RH. MJ and NN drafted the manuscript. All authors contributed to the interpretation of findings and writing the manuscript. All authors read and approved the final draft of the manuscript.

\section{Competing interests}

The authors declare that they have no competing interests.

Received: 16 February 2011 Accepted: 8 June 2011

Published: 8 June 2011

\section{References}

1. Arroyo JA, Winn VD: Vasculogenesis and angiogenesis in the IUGR placenta. Semin Perinatol 2008, 32(3):172-177.

2. Mayhew TM, Charnock-Jones DS, Kaufmann P: Aspects of human fetoplacental vasculogenesis and angiogenesis. III. Changes in complicated pregnancies. Placenta 2004, 25(2-3):127-139.

3. Lam C, Lim KH, Karumanchi SA: Circulating angiogenic factors in the pathogenesis and prediction of preeclampsia. Hypertension 2005, 46(5):1077-1085.

4. Grill S, Rusterholz C, Zanetti-Dallenbach R, Tercanli S, Holzgreve W, Hahn S, Lapaire O: Potential markers of preeclampsia-a review. Reprod Biol Endocrinol 2009, 7:70.

5. Levine RJ, Maynard SE, Qian C, Lim KH, England L, Yu KF, Schisterman EF, Thadhani $\mathrm{R}$, Sachs BP, Epstein $\mathrm{FH}$, et al: Circulating angiogenic factors and the risk of preeclampsia. N Engl J Med 2004, 350(7):672-683.

6. Maynard SE, Min JY, Merchan J, Lim KH, Li J, Mondal S, Libermann TA Morgan JP, Sellke FW, Stillman IE, et al: Excess placental soluble fms-like tyrosine kinase 1 (sFlt1) may contribute to endothelial dysfunction, hypertension, and proteinuria in preeclampsia. J Clin Invest 2003, 111(5):649-658.

7. De Vivo A, Baviera G, Giordano D, Todarello G, Corrado F, D'Anna R: Endoglin, PIGF and sFlt-1 as markers for predicting pre-eclampsia. Acta Obstet Gynecol Scand 2008, 87(8):837-842.

8. Reddy A, Suri S, Sargent IL, Redman CW, Muttukrishna S: Maternal circulating levels of activin A, inhibin A, sFlt-1 and endoglin at parturition in normal pregnancy and pre-eclampsia. PLoS One 2009, 4(2): e4453. 
9. Nevo O, Many A, Xu J, Kingdom J, Piccoli E, Zamudio S, Post M, Bocking A, Todros T, Caniggia I: Placental expression of soluble fms-like tyrosine kinase 1 is increased in singletons and twin pregnancies with intrauterine growth restriction. J Clin Endocrinol Metab 2008, 93(1):285-292.

10. Savvidou MD, Yu CK, Harland LC, Hingorani AD, Nicolaides KH: Maternal serum concentration of soluble fms-like tyrosine kinase 1 and vascular endothelial growth factor in women with abnormal uterine artery Doppler and in those with fetal growth restriction. Am J Obstet Gynecol 2006, 195(6):1668-1673.

11. Signore C, Mills JL, Qian C, Yu K, Lam C, Epstein FH, Karumanchi SA, Levine RJ: Circulating angiogenic factors and placental abruption. Obstet Gynecol 2006, 108(2):338-344.

12. Tikkanen M, Stenman UH, Nuutila M, Paavonen J, Hiilesmaa V, Ylikorkala O: Failure of second-trimester measurement of soluble endoglin and other angiogenic factors to predict placental abruption. Prenat Diagn 2007, 27(12):1143-1146.

13. Baumann MU, Bersinger NA, Surbek DV: Serum markers for predicting preeclampsia. Mol Aspects Med 2007, 28(2):227-244.

14. Kaaja R: Predictors and risk factors of pre-eclampsia. Minerva Ginecol 2008, 60(5):421-429.

15. Higgens JPT, Green S, eds: Cochrane handbook for systematic reviews of interventions. West Sussex, England: John Wiley \& Sons Ltd; 2008.

16. Baumann MU, Bersinger NA, Mohaupt MG, Raio L, Gerber S, Surbek DV: First-trimester serum levels of soluble endoglin and soluble fms-like tyrosine kinase-1 as first-trimester markers for late-onset preeclampsia. Am J Obstet Gynecol 2008, 199(3):266, e261-266.

17. Chaiworapongsa T, Romero R, Kim YM, Kim GJ, Kim MR, Espinoza J, Bujold E, Goncalves L, Gomez R, Edwin S, et al: Plasma soluble vascular endothelial growth factor receptor-1 concentration is elevated prior to the clinical diagnosis of pre-eclampsia. J Matern Fetal Neonatal Med 2005, 17(1):3-18.

18. Erez O, Romero R, Espinoza J, Fu W, Todem D, Kusanovic JP, Gotsch F, Edwin S, Nien JK, Chaiworapongsa T, et al: The change in concentrations of angiogenic and anti-angiogenic factors in maternal plasma between the first and second trimesters in risk assessment for the subsequent development of preeclampsia and small-for-gestational age. J Matern Fetal Neonatal Med 2008, 21(5):279-287.

19. Eskild A, Jeansson S, Jenum PA, Staff AC, Thadhani R, Karumanchi A Vatten $L$ : Levels of angiogenic factors in pregnancy and post-partum bleeding. Acta Obstet Gynecol Scand 2008, 87(10):1081-1083.

20. Rana S, Karumanchi SA, Levine RJ, Venkatesha S, Rauh-Hain JA, Tamez H, Thadhani R: Sequential changes in antiangiogenic factors in early pregnancy and risk of developing preeclampsia. Hypertension 2007, 50(1):137-142.

21. Smith GC, Crossley JA, Aitken DA, Jenkins N, Lyall F, Cameron AD, Connor JM, Dobbie R: Circulating angiogenic factors in early pregnancy and the risk of preeclampsia, intrauterine growth restriction, spontaneous preterm birth, and stillbirth. Obstet Gynecol 2007, 109(6):1316-1324.

22. Thadhani R, Mutter WP, Wolf M, Levine RJ, Taylor RN, Sukhatme VP, Ecker J, Karumanchi SA: First trimester placental growth factor and soluble fmslike tyrosine kinase 1 and risk for preeclampsia. J Clin Endocrinol Metab 2004, 89(2):770-775.

23. Vatten L, Eskild A, Nilsen TI, Jeansson S, Jenum PA, Staff AC: Changes in circulating level of angiogenic factors from the first to second trimester as predictors of preeclampsia. Am J Obstet Gynecol 2007, 196(3):239, e231236.

24. Wathen KA, Tuutti E, Stenman UH, Alfthan $H$, Halmesmaki E, Finne $P$, Ylikorkala O, Vuorela P: Maternal serum-soluble vascular endothelial growth factor receptor- 1 in early pregnancy ending in preeclampsia or intrauterine growth retardation. J Clin Endocrinol Metab 2006, 91(1):180-184.

25. Lynch AM, Murphy JR, Gibbs RS, Levine RJ, Giclas PC, Salmon JE, Holers VM: The interrelationship of complement-activation fragments and angiogenesis-related factors in early pregnancy and their association with pre-eclampsia. BJOG 2010, 117(4):456-462.

26. Noori M, Donald AE, Angelakopoulou A, Hingorani AD, Williams DJ: Prospective study of placental angiogenic factors and maternal vascular function before and after preeclampsia and gestational hypertension. Circulation 2010, 122(5):478-487.
27. Akolekar R, de Cruz J, Foidart JM, Munaut C, Nicolaides KH: Maternal plasma soluble fms-like tyrosine kinase- 1 and free vascular endothelial growth factor at 11 to 13 weeks of gestation in preeclampsia. Prenat Diagn 2010, 30(3):191-197.

28. Powers RW, Roberts JM, Cooper KM, Gallaher MJ, Frank MP, Harger GF, Ness RB: Maternal serum soluble fms-like tyrosine kinase 1 concentrations are not increased in early pregnancy and decrease more slowly postpartum in women who develop preeclampsia. Am J Obstet Gynecol 2005, 193(1):185-191

29. McKeeman GC, Ardill JE, Caldwell CM, Hunter AJ, McClure N: Soluble vascular endothelial growth factor receptor-1 (sFlt-1) is increased throughout gestation in patients who have preeclampsia develop. Am J Obstet Gynecol 2004, 191(4):1240-1246.

30. Romero R, Nien JK, Espinoza J, Todem D, Fu W, Chung H, Kusanovic JP, Gotsch F, Erez O, Mazaki-Tovi S, et al: A longitudinal study of angiogenic (placental growth factor) and anti-angiogenic (soluble endoglin and soluble vascular endothelial growth factor receptor-1) factors in normal pregnancy and patients destined to develop preeclampsia and deliver a small for gestational age neonate. J Matern Fetal Neonatal Med 2008, 21(1):9-23.

31. Steegers EA, von Dadelszen P, Duvekot JJ, Pijnenborg R: Pre-eclampsia. Lancet 2010, 376(9741):631-644.

32. Bishop JC, Dunstan FD, Nix BJ, Reynolds TM, Swift A: All MoMs are not equal: some statistical properties associated with reporting results in the form of multiples of the median. Am J Hum Genet 1993, 52(2):425-430.

33. Yaron Y, Heifetz S, Ochshorn Y, Lehavi O, Orr-Urtreger A: Decreased first trimester PAPP-A is a predictor of adverse pregnancy outcome. Prenat Diagn 2002, 22(9):778-782.

doi:10.1186/1477-7827-9-77

Cite this article as: Jacobs et al.: Levels of soluble fms-like tyrosine kinase one in first trimester and outcomes of pregnancy: a systematic review. Reproductive Biology and Endocrinology 2011 9:77.

\section{Submit your next manuscript to BioMed Central and take full advantage of:}

- Convenient online submission

- Thorough peer review

- No space constraints or color figure charges

- Immediate publication on acceptance

- Inclusion in PubMed, CAS, Scopus and Google Scholar

- Research which is freely available for redistribution

Submit your manuscript at www.biomedcentral.com/submit
C) Biomed Central 